Arab World English Journal (AWEJ) Volume 12. Number 4 December 2021

DOI: https://dx.doi.org/10.24093/awej/vol12no4.34

\title{
Reading Difficulties in English as a Second Language in Grade Five at a Saint Patrick's High School for Boys, Hyderabad- India
}

\author{
Zena Abdulameer Mohammad \\ Scholarships and Cultural Relations Department \\ University of Baghdad, Baghdad, Iraq \\ Corresponding Author: zena.am@uobaghdad.edu.iq
}

\begin{abstract}
Muhamad Hasbi
English Education Department, Faculty of Teacher Training and Education IAIN Salatiga, Salatiga, Indonesia
\end{abstract}

Received: 7/9/2021

Accepted:10/3/2021

Published:12/27/2021

\begin{abstract}
Reading is one of the essential components of the English language. Countries that use English as a second language (ESL) sometimes have difficulties in reading and comprehension. According to many researches, mother tongue has proved some interferences with learning a second language. This study investigated the results of reading difficulties of young second language learners in terms of accuracy, comprehension, and rate using the Neale Analysis of Reading Ability test. The study was carried out in one of the High Schools for Boys in Hyderabad, India and included Grade five, aged 10-12 years. In order to understand the reading difficulties of English as a second language, a qualitative approach was employed. Interview, reading tests, and observation were conducted as a data collection tool. The findings showed that these subjects had no specific language impairments but they had different degrees of language exposure and usage that led to poor accuracy, comprehension, and reading rate during reading English language texts. Five students (50\%) were classified at a low level of readers, three (30\%) at a high level, and two (20\%) at a mild level after evaluation of their compatibility between their chronological and reading age. It is suggested that the teachers should first assess students who struggle in reading accuracy and comprehension and then assist them with their language learning and acquisition that take place at school and home.
\end{abstract}

Keywords: Reading difficulties, young learners, poor accuracy, Neale Analysis of Reading Ability test, English as a Second Language

Cite as: Mohammad, Z. A., \& Hasbi, M. (2021). Reading Difficulties in English as a Second Language in Grade Five at a Saint Patrick's High School for Boys, HyderabadIndia. Arab World English Journal, 12 (4) 521 -535.

DOI: https://dx.doi.org/10.24093/awej/vol12no4.34 


\section{Introduction}

Reading in any language plays an essential role in our educational system and social lives. The reading process is the avenue for other English functions such as writing, vocabulary identification, use, grammar advancement, and excellent spelling (Chandran \& Shah, 2019, p.3372).

Reading skill differs from listening and speaking. It is the most essential skill among the four language skills: listening, speaking, writing, and reading as it can improve the overall language proficiency (Krashen \& Brown, 2007). It is also associated with an individual's success as it helps them comprehend written or printed materials that help them in their professional engagements and interactions. Countries that use English as a second language (ESL) sometimes have difficulties reading and comprehension.

Reading comprehension is not just realizing or understanding of individual words when our eyes pass over them. Instead, all comprehension models emphasize the need for readers to build up a mental representation of text, a process that requires integration across a range of sources of information from lexical features to knowledge concerning events in the world (Garnham, 2001; Gernsbacher, 1990).

Reading, understanding, and comprehension of the second language, especially English, pose a great challenge to the learners, teachers, and parents since young learners may lack required exposure to the proper enabling environment, social milieu, and peers well-versed in linguistic abilities. Nature and nurture play their part in creating reading and other linguistic skills in young learners with English as a second language (ESL). Nurture and socialization play a predominant role in overcoming ESL learning barriers in young children.

Across the world, a second language (other than mother tongue) is acquired through Reading in classrooms, often without any exposure to English outside it. In India also, a child acquires efficiency in ESL, the second language, generally through socialization and in classrooms. Therefore, oral proficiency may not be a good predictor of reading comprehension, and speech ability in the ESL context in India, where students learn a second language through reading rather than speaking. Most of the students start speaking English only after five years of exposure to English, whereas they start reading and writing their mother tongue fluently by this time. "These children thus confront with the task of learning to read in a language that they have yet to master orally. Because reading instruction strongly builds on oral language proficiency, second-language speaking children may therefore experience a considerable gap." (Droop and Verhoeven, 2003: 78)

This study aimed to determine the reading difficulties of young second language learners in terms of accuracy, comprehension and reading speed in one of the High Schools for Boys in Hyderabad, India. It also investigated if these difficulties were due to a lack of proper English language exposure or genetic language impairments. This study posed three primary research questions:

1. What are the language and literacy backgrounds of the learners?

2. What are the observations of learners' reading performance using NARA test? 
3. What tendency could be observed about learners' reading performance based on the test?

\section{Literature Review}

It is very important to evaluate critically the reading difficulties of a child, i.e. elements behind a child's slow and inaccurate reading and writing skills, possible problems encountered in reading comprehension both in L1 and L2 levels, especially the English language. A learner needs to be given sufficient time to learn English as a second language so that one can realize one's full potential in linguistic and academic development.

Some of the difficulties experienced in ESL countries come from various factors that are beyond human control. According to Chandran \& Shah (2019, p.3372), problems in reading and comprehension emanate from environmental, instructional, and biological sources. These causes mean that the surrounding that one is born and brought up determines their ease of grasping new languages and, in this case, English.

Similarly, the modes of instruction that one receives at an early age or during their growth determine their ability to grasp reading and comprehension. Lastly, the combination of the biological parents determines the origin of a person. It would ascribe one to a specific genetic makeup that either makes them easy to learn languages or not.

Another difficulty that ESL learners face is because of the setup of the English language. The words in English can be ambiguous and of unfamiliar vocabulary to countries that use it as a second language (Mohammed \& Rashid, 2017, p.429). Also, these learners have limited time to cognitively process texts presented to them and output the required responses, especially when around natives. Some of the other sources originate from the wrong pronunciation of words due to ethnicity, encountering new words, not understanding the meaning of the words, and poor reading habits (Mohammed \& Rashid, 2017, p.427). Looking at these scenarios, ESL students would need more time and commitment to understand and read English to use it around others.

Young learners are usually presented with the opportunity of strengthening their reading skills from an early age. At this age, the students still struggle with decoding phonetic knowledge, word recognition, and comprehension (Sardor, Oyshajon, \& Rushana, 2020, p.76). As a result, the students disengage themselves from reading tasks, have lowered self-confidence in reading new words, are frustrated in simple reading tasks, and are discouraged by their lack of success.

India is a multilingual country; it adopted twenty-two official languages and boasts of having the world's second-highest (780) number of languages, after Papua New Guinea (839 speeches). The English language holds a prominent place in India. English is one of the principal languages in private schools right from kindergarten onwards. The government of India has the policy to provide school education to the children, usually through the mother tongues and the official languages of the states or union territories. Therefore, English was taught as a "subject" in the "regional-medium" schools throughout the country. Tarinayya highlighted the importance and popularity of learning English in children in the statement: "India - where every schoolgoing child has to be taught English...." (Amritavalli, 2001, p. 216). English was introduced as a 
second or third language between the $4^{\text {th }}$ and $7^{\text {th }}$ years, depending on the policy of individual states of the Indian republic.

National Council for Educational Research and Training (NCERT), in a study conducted in 2003, found that ESL was introduced in class I or class III in 26 states/union territories while only seven states/union territories introduced it as late as in class IV or class V.

In fact, young learners across India, i.e., children aged 7-11 years, start learning English as a foreign or second language at the very beginning of their formal education, viz. age up to seven years (Enever, 2009; Graddol, 2006; Savić, 2013). It is not important matter for children in India to read in a language or languages that they speak in their homes. They may learn to read in a language they do not yet know to speak, let alone understand. (Elley, 2001) described this situation clearly:

Children in developing countries face multiple handicaps in learning to read (...) Children in most developing countries expected to become literate in a non-native language or dialect. Whereas the majority of children in (the developed, GR) countries have the luxury of learning to read and write in their mother tongue, those in most African, South American, South Asian and Oceanic schools are struggling to cope with English, (...) or some other metropolitan language, usually a legacy of earlier colonial masters. This challenge of acquiring literacy in a second language (...) is true for most developing countries. (p.128)

\section{Neale Analysis of Reading Ability- second Edition (NARA II)}

The Neale Analysis of Reading Ability (NARA) is a verbal reading test like a questionanswer type test for children in the age range of six to twelve years usually. Children read aloud six short stories of increasing difficulty. Any errors by the children are corrected by the tester, and the required time to read English passages is noted. After each story, comprehension- based questions are asked to know the understanding of the learners. Some of the questions may be answered using verbatim memory, while others may require help and intervention by the tester.

The testers should terminate NARA test when the learner completes reading all six passages or when they find it too tough to continue. It depends on the number of reading errors committed. Separate standard scores and reading- chronological age equivalent scores are generated for text reading accuracy, reading comprehension, and reading speed.

The latter is measured by timing the passages read and converting this into words per minute over the total number of passages read. Hill, Long, Douglas, Tobin \& Grimley (2005), in their study, found that the NARA test classifies reading errors into six categories: substitutions, refusals, additions, omissions, mispronunciations, and reversals. The tester can stop the evaluation of the learner at anytime if a child commits more than twelve errors in a given text. If a child commits more than sixteen errors in any single passage, the test stands discontinued immediately, and all six passages are not asked to be read. Furthermore, when administrating a reading ability test, optimal conditions can be suggested. 
The test is administered in a peaceful place devoid of any distractions and interruptions to the children. It is preferring to use NARA in the oral reading test on account of the following reasons;

1. The results obtained by using NARA enable the assessor to select appropriate reading materials suited to the ability of individual students;

2. NARA allows monitoring the adoption of particular reading skills and helps to formulate specific intervention strategies;

3. NARA provides standard age scores, reading ages, and important information for proper evaluation of linguistic skills in young learners.

\section{Methods}

This study was qualitative research, which enabled the researchers to generate the data documenting the students' language, literacy profiles, and reading performance through interviews, reading tests, and observation. The study was conducted in Saint Patrick's High School for Boys, Hyderabad- India. This school had more than 2,000 students on its roll. Two researchers visited the school before administering the actual test to be familiar with the location, facilities, authorities, infrastructure, and administration of the school. The test was conducted on alternate days of the week.

\section{Participants}

Based on the researchers' request, the school principal provided ten children having different levels of English proficiency (good, medium, poor) as the subjects of the study. They were all male students of Grade five, age between10-12 years. The examination was administered for two days; each testing day had one researcher examining five student samples. Another researcher helped in managing the administrative necessities and running the research procedure as per study design.

\section{Instrument}

To determine the reading difficulties of young second language learners who had different native language backgrounds, both researchers designed a semi-structured interview, a set of NARA II test booklets (the test manual), assessment forms, notes book, pencil, audio recorder, a stopwatch, and observation as a data collection tool. The data was analyzed qualitatively,

\section{Procedure and Materials}

In the pre-reading stage, as it is shown in figure (1) below, the researchers welcomed the participants to enter the experiment place - a quiet, free from distraction and interruption room -one after another. The researcher commenced the test through opening small discussions with the participants. Questions were asked before start reading such as talking about their favorite hobbies, personal information, kind of spoken language at home and school, and literacy backgrounds. The pre-reading stage was done as a warm-up exercise. The data were documented in a pre-printed student profile form. 


\begin{tabular}{|l|l|l|l|}
\hline \multicolumn{1}{|c|}{ Pre-reading } & \multicolumn{1}{c|}{$\begin{array}{c}\text { While-reading } \\
\text { - Testing with practice }\end{array}$} \\
passage. & \multicolumn{1}{c|}{ Post-reading } \\
- Opening discussion. & $\begin{array}{l}\text { - Deciding starting level of } \\
\text { - Gathering student's information. } \\
\text { - Introducing the test to students. } \\
\text { - Setting audio recording on. }\end{array}$ & $\begin{array}{l}\text { - Closing test. } \\
\text { - Noting reading errors. } \\
\text { - Noting comprehension } \\
\text { answers. } \\
\text { - Noting the time taken. } \\
\text { - Deciding when to stop } \\
\text { testing. }\end{array}$ \\
\hline
\end{tabular}

Figure1. Test administration process

Friendly atmosphere was created during the test to ensure that the participants have no inhibitions and have a free and frank discussion. More clarifications and explanations were given to the participants to clear any ambiguity concerning the test so they become more interactive and feel free perplexed.

As this test was taken by considerably young learners, before proceeding with the reading session, the tester gave obvious and pressure-free instructions to ensure that the students know the test procedure, feel comfortable, and do their best during the test. For instance,

"Look at the picture and then read the story to me. If you come across a hard word, try reading it yourself before I help you. I am going to record the time it takes you to read, but it is more important to read carefully and remember what you read. In the end, I shall ask you some questions, so try to remember the story as you read it".

A set of Neale Analysis of Reading Ability-second edition (NARA II) was used in the initial test, which provided test administration guidelines, practice and reading passages and two other forms, namely Diagnostic Tutor Form and the Supplementary Diagnostic Tests Form. As per the set guidelines, the researchers began facilitating the test by allowing the students to read a practice passage. Several practice passages in the test book were classified by age; thus, the suitable passage was picked above 7-year-olds.

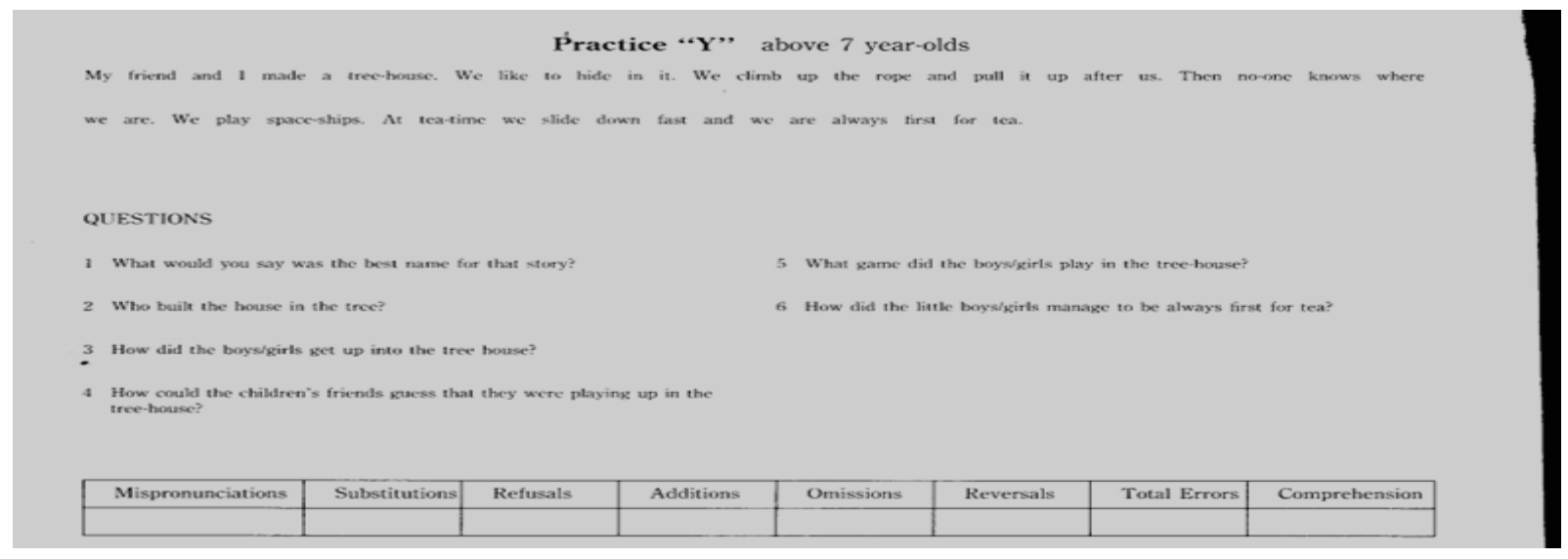

Figure 2. Illustration of the passages in NARA II test book 
As part of the participant's assessment, six reading passages were prepared to read orally by them. See appendix (A) - table 1.

While students read the texts, testers had to multitask the instructions and record everything that was going on. The students start reading the practice passage and deciding on which level of actual reading they were (the better result of students 'practice passage reading, the higher level they could start their actual reading passage reading from), noting down students' classified reading errors, namely words: mispronunciations, substitutions, refusals, additions, omissions, reversals in the Diagnostic Tutor Form and Supplementary Diagnostic Tests Form, making notes of students' answers to the comprehension questions in each passage, writing down the time taken by students to complete the test, and deciding when to stop testing them.

The tester decides to stop the test once the students feel hesitated several times or committed many errors; thus it was not necessary for all students to finish reading the whole passages. In the NARA II, every inaccuracy in reading was counted as an error and recorded in the individual record. The categorization of errors was classified during and after students' reading. The classification included: mispronunciations, substitutions, refusals, additions, omissions, and reversals. Hesitations and self-corrections were not a part of errors.

According to the allotted time required for the students to read every passage, the time was recorded from the first to the last. After that, the tester asked the students comprehension-based questions as soon as they finished reading the passage. They were encouraged to answer questions in their own words. Ten to twelve seconds of pause was compensated before they responded to the questions; when they did not, the tester asked the following question without answering the previous one. The tester decides to terminate the test in case the students exceed the maximum number of errors per level. The errors were 16-20 errors for level seven, without giving any comprehension questions after duly recording time spent and the number of errors made.

The tester made several interruptions, such as prompting the correct word when the students kept on reading the text while reading a word wrongly. The tester also helped the student to recite the word correctly when he was reading hesitate or attempting to decode phonetically but failed within five to seven seconds. The test session was shortly closed after one student finished with the passages reading. The tester had five minutes interval to scan all the recorded data and check whether the answers were completed or not. Then another student was called for conducting a similar test.

\section{Data Collection and Analysis}

Primary sources for data collection included (a) Interview with the school principal to collect information about school and students, (b) Interview with the students to collect their personal information, and (c) Observation on students' passages, reading tests to garner specific information on students' reading achievements, and their comprehension and accuracy issues. The tools used in this study included a set of NARA II test booklets (the test manual), assessment forms, notes, a pencil, and a stopwatch. The data was analyzed qualitatively by cross-referencing all the findings in each phase of the data collection. 


\section{Students' Profile}

The highlighted areas of students' language background and reading performance extracted were clarified in the appendix (B) - table (2) which were extracted from the research study. The pre-reading stage provided the information on the ten tested subjects.

\section{Results and Discussion}

The study results surprisingly revealed that the school was attended by students with varied native language backgrounds, with English, Telugu, and Urdu being the most common languages even though they did not project dominancy. These three languages are also equally exposed by mass media such as newspapers and TV programs. At home, most students spoke both native and English languages, whereas, at school, they spoke English and probably the native language with their teachers and their school friends who might have the same local language. The fact that they studied in English medium school where Telugu is the native language. The national language of their country is Hindi which mirrors a piquant situation in which students shared almost equal struggle in terms of their language learning and acquisition.

Students with English as their mother tongue might have a little more ease when it came to learning. At school, English was taught through speaking and writing. Students were supposed to excel with similar competency in English depending on how committed they were performing their academic learning.

\section{Learners' Reading Performance}

The observation through a series of tests produced a record of students' reading errors, comprehension, and reading speed. Both appendix (C) - tables (3) and appendix (D) - table (4) provide information about the level of reading performance of students in three areas. They include also examples of a student's error archiving.

\section{Level Achievement}

Out of ten students, only three could cover reading all the levels. Two students read to L5 and two others read to L4, while three students stopped only at Level three. Based on the observation, SH, the least achiever on Day one of the test, read the passages very fast. He was the fastest reader though he was not the best performer in both accuracy and comprehension. He committed many errors such as omissions and deleted or missed a few words. This means that quick reading may lead to reading inaccuracy and a lower level of comprehension. A contrary situation was experienced on Day two by JA, who stopped at the same Level as SH where his termination at Level four was in parallel with the fact that he was the slowest reader among all the participants. Meanwhile, TC, the student with maximum languages exposure and use (Sathri, English, Hindi, and Telugu), read the texts very carefully but performed poorly at reciting and comprehending of text.

\section{Level Difficulty}

The average points for the number of errors, correct answers, and the time spent to read were generated to identify the degree of difficulty of the passages. The level was determined from a lower to a higher level in a linear pattern as per the testing-set criteria. The following chart showed the difficulty movement from level to level: 


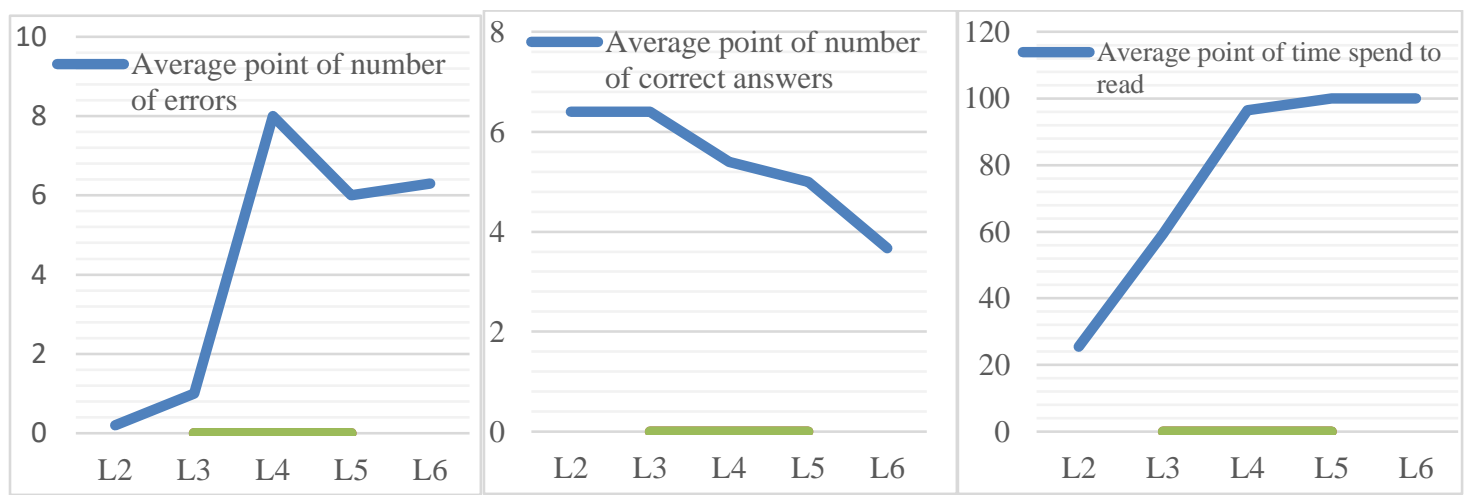

Figure 3. The movement of difficulty in terms of accuracy, comprehension, and rate

According to the graphs above which show the movement of difficulty in terms of accuracy, comprehension, and rate especially in level (four, five, six), students found that most difficulty was in decoding and reading passages. However, the fact that more questions at higher levels were harder to answer indicates that lower-level passages had been more understandable than higher-level ones. Similarly, lower-level passages took a shorter time to read, and this trend continued throughout the levels.

In this study, it is also noticed that the difficulty movements for the contexts of comprehension and rate projected a proportional leap which means that in terms of comprehension, Level two was more comprehensible than Level three, Level three was more comprehendible than Level four, and so forth. In contrast, in terms of rate, students took a longer time to read the passage of Level two than that of Level one and took longer of Level three than that of Level two and so forth. Meanwhile, the accuracy factor across the passages drew nonlinear progress; students made more inaccuracy mistakes in Level four than in Level five and also in Level five than in Level six.

The findings suggests that accuracy challenges among Level four, Level five, and Level six passages had not mirrored the nature of the NARA II test design. The other reason could be the case of students' background language interference in which vocabularies used in Level four and Level five had more complexion to cater than in Level five and Level six for Indian second language learners. If that was right, revision of passage composition is of primary recommendation.

Based on the comparison between the chronological age and reading age as shown in appendix (E) - table (5), students (TC, JA, PO, PR, NA, and SS) underperformed the test, with an exception for PO's and SS's reading which was classified as ideal one. Unique treatment should be given for students (PR, NA, and SS) as both their accuracy and comprehension were approximately three years behind ideality. SH was surprisingly being the fastest reader among all the participants. He displayed his reading accomplishment though his accuracy still need a significant improvement. Results of other students: NP, AJP, and SI were awe-inspiring as NP \& SI passed the test well, however, AJP failed to pass the test because he did not attempting the minimum number of questions. 
It is to be noticed that the majority of the subjects $(8: 2)$ showed quality of their performance on both word recognition processes and reading comprehension processes. Therefore, there is a strong tendency between the development of learners' accuracy and comprehension that are likely to go hand in hand in the context of reading activities. Moreover, cross-referencing students' score achievement with their language and literacy profile, gives enough testimony that students who use two active languages (SI, AJP, NP) have more potential than those with more active languages (SS, NA). It could also be due to the use of two languages which one of them might be used limitedly with family members and few people as the case in student (PR). Finally, to recap students' rapport while taking the whole test, figure (3) below illustrates the individual reading achievement in the form of the simple view of reading diagram.

The findings of the study refer clearly that these children with reading difficulties, especially in the elementary schools had no specific language impairments but they had different degrees of language exposure that led to poor accuracy, comprehension, and reading rate. The findings also proved the shyness of these students while reading passages in English language in front of their peers and teachers. Therefore, their situation became complicated and further aggravated the learning deficit of the students in respect of the second language.

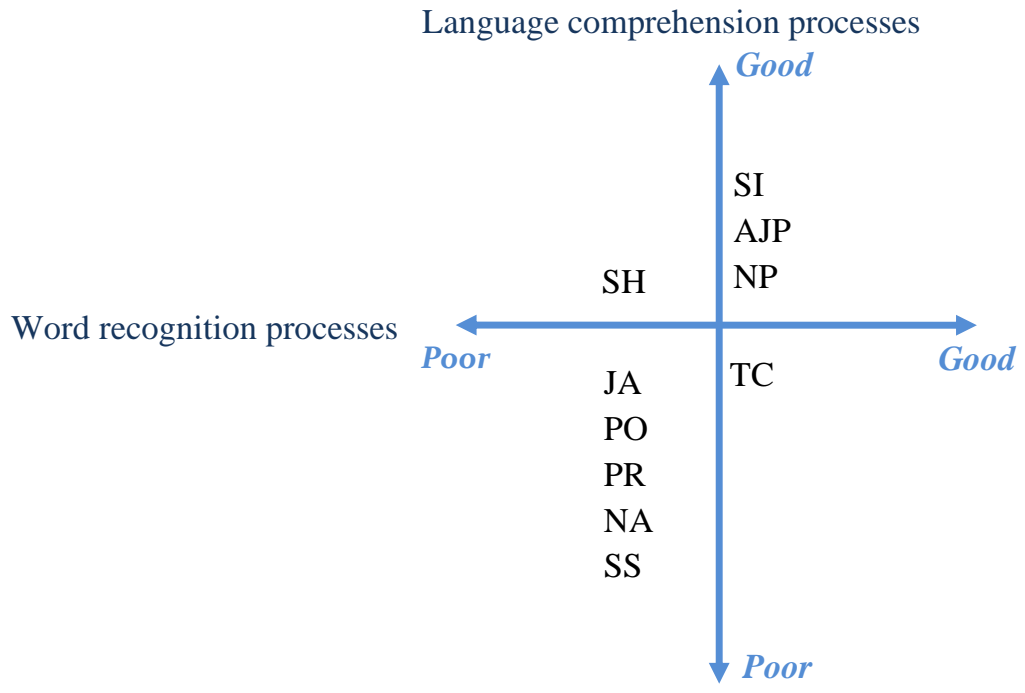

Figure 4. The simple view of reading

\section{Conclusion}

The current study provides significant insight into the development of initial reading in English as a second language (ESL). The aim of the study was to examine reading difficulties of young second language learners in terms of accuracy, comprehension, and rate using Neale Analysis of Reading Ability (NARA II) test. Listening to the participants who read different types of texts in a second language gave valuable information about their development as readers and about their difficulties in reading while performing the tasks. The findings of this study revealed that the accuracy difficulty level throughout the whole passages did not go linear. It also 
showed that the difficult aspects which need improvement in priority varied from student to another. The ratio of passing the NARA II reading test, based on comparing their chronological and reading age, was 3:2:5 for good, mild, and poor achievers, respectively.

These findings highlight the need for more frequent exposure to and use of English in increasing the ability to read accurately, comprehensibly, and fluently. Other difficulties encountered were that the participants did not recognize mistakes like omissions, substitutions, and mispronunciation, which adversely affected the participants' comprehension and accuracy levels. According to the findings, the recommendations below were made:

i) At schools in general, teachers need to provide solutions such as giving unique treatments to low performers or changing their approaches of teaching, i.e. reading.

ii) More research using the NARA II reading test need to be conducted with multiple illiteracies, language, gender, and other backgrounds of the learners.

iii) Parents should share their responsibilities to ensure the learning process of their children. They should encourage them to read different materials such as stories and science fiction in their free time to improve their reading. Besides, bring their children to school at a younger age to encourage their abilities development in writing and reading.

\begin{abstract}
About the Authors:
Zena Abdulameer Mohammad is currently working at Scholarships and Cultural Relations Department, University of Baghdad. She is university instructor teaching English as Foreign Language to undergraduate's students, College of Veterinary Medicine, University of Baghdad. She is also delivering English language training courses at Development and Continuing Center to all learning levels for EFL learners. She got her B.A. in Translation, Mustansiriyah University, Baghdad-Iraq and her M.A. in Teaching English as a Second Language (TESL), The English and Foreign Languages University (EFLU), Hyderabad-India. Her main interest in developing reading, and listening skills through using multimedia technology. ORCID: https://orcid.org/0000-0001-5569-049X
\end{abstract}

Muhamad Hasbi is an English education lecturer in the Teacher Training and Education Faculty, IAIN Salatiga, Indonesia. He has involved in several Indonesian and American Language Massive Open Online Courses (LMOOCs) projects as both a participant and a facilitator, and has grown teaching and research interest in technology-enhanced language learning. ORCID: https://orcid.org/0000-0001-7446-2062

\title{
References
}

Amritavalli, R. (2001). Applied research in language education. In C.J. Daswani (Ed.), Language education in multilingual India. (pp. 210-263). New Delhi: UNESCO.

Chandran, Y., \& Shah, P. M. (2019). Identifying learners' difficulties in ESL reading comprehension. Creative Education, 10,3372-3384. https://doi.org/10.4236/ce.2019.1013259.

Droop, M., \& Verhoeven, L. (2003). Language proficiency and reading ability in first-and second- language learners. Reading research quarterly, 38(1), 78-103.

DOI: https://doi.org/10.1598/RRQ.38.1.4 
Elley, W. (2001). Editorial. Guest editor's introduction. International Journal of Educational Research, 35, 127-135.

Enever, J. (2009). Can today's early language learners in England become tomorrow's plurilingual European citizens. In M. Nikolov, (ed.), Early learning of foreign languages: Processes and outcomes (pp. 15-29). Toronto: Multilingual Matters.

Garnham, A. (2001). Mental models and the interpretation of anaphora. Psychology Press.

Gernsbacher, M.A. (1990). Language comprehension as structure building. Hillsdale, NJ: Erlbaum.

Graddol, D. (2006). English Next. London: British Council.

Hill, E., Long, R., Douglas, G., Tobin, M., \& Grimley, M. (2005). Neale analysis of Reading Ability for readers with low vision. A supplementary manual to aid the assessment of partially sighted pupils' reading using the Neale Analysis of Reading Ability (NARA) Birmingham, UK: Visual Impairment Centre for Teaching and Research.

Krashen, S., \& Brown, C. L. (2007). What is academic language proficiency? STETS Language \& Communication Review, 6(1), 1-5.

Mohammad, Q., \& Rashid, AR. (2017). Reading comprehension difficulties among EFL learners: the case of first and second-year students at Yarmouk University in Jordan. Arab World English Journal, 8(3) DOI: https://dx.doi.org/10.24093/awej/vol8no3.27.

National Focus Group on English - Position Paper. (2005). New Delhi: NCERT.

Sardor, S., Oyshajon, A., \& Rushana, T. (2020). The difficulties of reading among young learners in online education. European Journal of Research and Reflection in Educational Sciences, 8(12), 76-79. 10.5281/zenodo.4347316.

Savić, V. (2013). Using stories in theme-based instruction. Uzdanica, X(1), 169-186.

\section{Appendixes}

\section{Appendix A}

Table 1. Details of six main reading passages in NARA II test book

\begin{tabular}{|c|c|c|c|}
\hline Title of passage & Level of each passage & Number of words in each passage & $\begin{array}{c}\text { Number of comprehension } \\
\text { questions in each passage }\end{array}$ \\
\hline Road Safety & level 2 & 52 & 8 \\
\hline Ali & Level 3 & 73 & 8 \\
\hline Jan & Level 4 & 96 & 8 \\
\hline The fox & Level 5 & 117 & 8 \\
\hline Migration & Level 6 & 141 & 8 \\
\hline
\end{tabular}

\section{Appendix B}

Table 2. Students' language and literacy background

\begin{tabular}{|c|c|c|c|l|}
\hline Initial name & Age & Mother tongue & Other spoken languages & Language exposure and use \\
\hline NP & 10,04 & English & Hindi, Telugu (passive) & $\begin{array}{l}\text { - spoke English to family } \\
\text { members and teachers. } \\
\text { - spoke English and Hindi } \\
\text { with friends. } \\
\text { - watched cartoons and } \\
\end{array}$ \\
& & & & $\begin{array}{l}\text { news in English. } \\
\text { - read book, stories, and } \\
\text { newspapers in English. }\end{array}$ \\
\hline SI & 11,08 & Urdu & English (equally used as his Urdu) & $\begin{array}{l}\text { - spoke in English and Urdu } \\
\text { with family and friends. }\end{array}$ \\
\hline
\end{tabular}


Arab World English Journal (AWEJ) Volume 12. Number 4. December 2021

Reading Difficulties in English as a Second Language in Grade Five

Mohammad, \& Hasbi

\begin{tabular}{|c|c|c|c|c|}
\hline & & & & $\begin{array}{l}\text { - spoke only in English with } \\
\text { his teachers. } \\
\text { - watched cartoons, cricket, } \\
\text { and news in English. } \\
\text { - read books and } \\
\text { newspapers in English. }\end{array}$ \\
\hline $\mathrm{TC}$ & 10,04 & Sathri (Marathi-Hindi) & English, Telugu & $\begin{array}{l}\text { - spoke in Sathri and } \\
\text { English with the family. } \\
\text { - spoke in Sathri, English, } \\
\text { Hindi, and Telugu with } \\
\text { friends. } \\
\text { - spoke in English only with } \\
\text { his teachers. } \\
\text { - watched cartoon in } \\
\text { English/Hindi, series in } \\
\text { Hindi. } \\
\text { - read books in } \\
\text { English/Hindi, newspapers } \\
\text { in English. }\end{array}$ \\
\hline $\mathrm{SH}$ & 10,07 & Urdu & English, Telugu (passive) & $\begin{array}{l}\text { - spoke Urdu and English } \\
\text { with relatives and friends. } \\
\text { - spoke only in English with } \\
\text { his teachers. } \\
\text { - watched cartoon, news, } \\
\text { football, baseball in English } \\
\text { - read books and } \\
\text { newspapers in English. }\end{array}$ \\
\hline AJP & 10,09 & Telugu & English, Telugu (passive) & $\begin{array}{l}\text { - spoke Telugu and English } \\
\text { with family members. } \\
\text { - watched TV programs in } \\
\text { English/Hindi/Telugu. } \\
\text { - read books and } \\
\text { newspapers only in English. }\end{array}$ \\
\hline JA & 10,01 & English & Hindi & $\begin{array}{l}\text { - watched TV programs in } \\
\text { English/Hindi. } \\
\text { - read books and } \\
\text { newspapers in } \\
\text { English/Hindi. }\end{array}$ \\
\hline $\mathrm{PO}$ & 10,08 & Telugu & English, Hindi (passive) & $\begin{array}{l}\text { - watched TV programs in } \\
\text { Telugu/English/Hindi. } \\
\text { - read books and } \\
\text { newspapers in } \\
\text { Telugu/English/Hindi. }\end{array}$ \\
\hline PR & 10,07 & Konkani & English & $\begin{array}{l}\text { - watched TV programs in } \\
\text { English. } \\
\text { - read books and } \\
\text { newspapers in English. }\end{array}$ \\
\hline NA & 10,03 & Hindi & English, Telugu & $\begin{array}{l}\text { - watched TV programs in } \\
\text { English/Hindi. } \\
\text { - read books and } \\
\text { newspapers in Hindi. }\end{array}$ \\
\hline SS & 10,06 & Telugu & English, Hindi (passive) & $\begin{array}{l}\text { - watched TV programs in } \\
\text { Telugu/English/Hindi. } \\
\text { - read books and } \\
\text { newspapers in }\end{array}$ \\
\hline
\end{tabular}


Arab World English Journal (AWEJ) Volume 12. Number 4. December 2021

Reading Difficulties in English as a Second Language in Grade Five

Mohammad, \& Hasbi

Telugu/English/Hindi.

Table 3. Students' reading performance

\section{Appendix C}

\begin{tabular}{|c|c|c|c|c|c|c|c|c|c|c|c|c|c|c|c|c|}
\hline \multirow{2}{*}{ No. } & Initial & \multicolumn{4}{|c|}{ nome } & na Errors & \multicolumn{4}{|c|}{ No. Of Correct Answers } & \multicolumn{5}{|c|}{ Time Spent to Read } \\
\hline & & L2 & L3 & L4 & L5 & L6 & L2 & L3 & L4 & L5 & L6 & L2 & L3 & L4 & L5 & L6 \\
\hline 1. & NP & 0 & 1 & 7 & 10 & 11 & 6 & 8 & 7 & 3 & 2 & 23 & 36 & 84 & 75 & 87 \\
\hline 2. & SI & 0 & 0 & 4 & 0 & 2 & 8 & 7 & 7 & 8 & 5 & 21 & 36 & 74 & 84 & 99 \\
\hline 3. & TC & 0 & 2 & 11 & 14 & $/$ & 5 & 5 & 4 & 4 & $/$ & 34 & 51 & 114 & 139 & $/$ \\
\hline 4. & SH & 1 & 2 & 14 & $/$ & $/$ & 8 & 7 & 7 & $/$ & $/$ & 16 & 41 & 65 & $/$ & $/$ \\
\hline 5. & AJP & 0 & 0 & 4 & 0 & 6 & 5 & 5 & 3 & 5 & 4 & 22 & 39 & 68 & 83 & 114 \\
\hline 6. & JA & 0 & 4 & 15 & $/$ & $/$ & 7 & 2 & 4 & $/$ & $/$ & 36 & 88 & 187 & $/$ & $/$ \\
\hline 7. & PO & 4 & 5 & 15 & 16 & $/$ & 6 & 0 & 3 & 3 & $/$ & 27 & 42 & 83 & 119 & $/$ \\
\hline 8. & PR & 4 & 10 & $/$ & $/$ & $/$ & 6 & 3 & $/$ & $/$ & $/$ & 25 & 87 & $/$ & $/$ & $/$ \\
\hline 9. & NA & 4 & 9 & $/$ & $/$ & $/$ & 5 & 5 & $/$ & $/$ & $/$ & 26 & 91 & $/$ & $/$ & $/$ \\
\hline 10. & SS & 1 & 7 & $/$ & $/$ & $/$ & 4 & 3 & $/$ & $/$ & $/$ & 25 & 82 & $/$ & $/$ & $/$ \\
\hline \multicolumn{1}{|c|}{ Total } & 14 & 40 & 70 & 40 & 19 & 60 & 45 & 35 & 23 & 11 & 255 & 593 & 675 & 500 & 300 \\
\hline Total average & 1,4 & 4 & 10 & 8 & 6,3 & 6 & 4,5 & 5 & 4,6 & 3,7 & 25,5 & 59,3 & 96,4 & 100 & 100 \\
\hline
\end{tabular}

Appendix D

Table 4. Level-wise analysis of sample of error typologies of the students

\begin{tabular}{|c|c|c|c|c|c|c|c|c|}
\hline \multicolumn{9}{|c|}{ Subject: NP } \\
\hline Level & Mispronunciations & Substitutions & Refusals & Additions & Omissions & Reversals & & $\mathrm{AL}$ \\
\hline L2 & - & - & - & - & - & - & 0 & \\
\hline L3 & - & $\begin{array}{c}\text { seems } \\
\text { (seemed) }\end{array}$ & - & - & - & - & 1 & \\
\hline L4 & $\begin{array}{l}\text { dinghi (dinghy) } \\
\text { mountenless } \\
\text { (motionless) }\end{array}$ & $\begin{array}{c}\text { Driving } \\
\text { (diving) } \\
\text { followed } \\
\text { (following) } \\
\text { driver (diver) }\end{array}$ & - & - & $\begin{array}{c}\text { Kell(Kells } \\
\text { ) } \\
\text { bubble } \\
\text { (bubbles) }\end{array}$ & - & 7 & \\
\hline L5 & $\begin{array}{c}\text { frisis (feats) } \\
\text { alightning } \\
\text { (alighting) } \\
\text { expenditions } \\
\text { (expeditions) } \\
\text { skrit (skirted) } \\
\end{array}$ & $\begin{array}{c}\sin (\text { scent) } \\
\text { responsibility } \\
\text { (responsibilitie } \\
\text { s) } \\
\text { too (through) } \\
\text { an (the) }\end{array}$ & - & - & $\begin{array}{c}\text { back } \\
\text { (backs) } \\
\text { pursuer } \\
\text { (pursuers) }\end{array}$ & - & $\begin{array}{l}1 \\
0\end{array}$ & 29 \\
\hline L6 & $\begin{array}{c}\text { consideable } \\
\text { (considerable) } \\
\text { rigyeres (rigorous) } \\
\text { flending } \\
\text { (fledglings) } \\
\text { yunnering } \\
\text { (unnering) }\end{array}$ & $\begin{array}{c}\text { swallowed } \\
\text { (swallows) } \\
\text { itself (instead) } \\
\text { was (with) }\end{array}$ & - & - & $\begin{array}{c}\text { season } \\
\text { (seasonal) } \\
\text { journey } \\
\text { (journeys) } \\
\text {... (it) } \\
\text { easter } \\
\text { (easterly) }\end{array}$ & - & $\begin{array}{l}1 \\
1\end{array}$ & \\
\hline
\end{tabular}

Appendix E

Table 5. Students' score summary in relation to their chronological age and reading age

\begin{tabular}{l|l|l|l}
\hline Students' & Chronological & Reading Age & Standardized Score \\
\hline
\end{tabular}


Arab World English Journal (AWEJ) Volume 12. Number 4. December 2021

Reading Difficulties in English as a Second Language in Grade Five

Mohammad, \& Hasbi

\begin{tabular}{|c|c|c|c|c|c|c|c|}
\hline Initial & Age & Accuracy & Comprehension & Rate & Accuracy & Comprehension & Rate \\
\hline NP & $10: 04$ & $10: 10$ & $11: 04$ & $\begin{array}{c}12: 10 \\
+\end{array}$ & 102 & 105 & 111 \\
\hline SI & $11: 08$ & $12: 10+$ & $12: 10+$ & $\begin{array}{c}12: 10 \\
+\end{array}$ & 113 & 113 & 104 \\
\hline TC & $10: 04$ & $9: 10$ & $9: 04$ & $8: 10$ & 93 & 93 & 92 \\
\hline SH & $10: 07$ & $8: 06$ & $10: 04$ & $\begin{array}{c}12: 10 \\
+\end{array}$ & 88 & 98 & 115 \\
\hline AJP & $10: 09$ & $12: 10+$ & $10: 04$ & $12: 05$ & 113 & 97 & 106 \\
\hline JA & $10: 01$ & $8: 04$ & $8: 04$ & $7: 02$ & 89 & 87 & 83 \\
\hline PO & $10: 08$ & $7: 11$ & $8: 01$ & $10: 08$ & 85 & 84 & 99 \\
\hline PR & $10: 07$ & $7: 05$ & $7: 07$ & $9: 08$ & 81 & 80 & 95 \\
\hline NA & $10: 03$ & $7: 04$ & $7: 08$ & $9: 04$ & 81 & 83 & 95 \\
\hline SS & $10: 06$ & $7: 11$ & $7: 01$ & $10: 01$ & 85 & 76 & 97 \\
\hline
\end{tabular}

